\title{
Development and validation of three methods: liquid chromatography, flow injection analysis and UV spectrophotometry for the routine control of nystatin capsules
}

\author{
M Herold, I May, A Nicolas
}

Service Pharmacie, Hôpitaux de Brabois, Allée du Morvan, Vandoeuvre Cedex, France

\section{Correspondence to} Dr M Herold, Service de Pharmacie, Hôpitaux de Brabois, Allée du Morvan, Vandoeuvre Cedex F-54511, France; marineherold@gmail. com

Received 3 June 2014 Revised 18 July 2014 Accepted 29 July 2014 Published Online First 27 August 2014

\section{ABSTRACT}

Objectives As an alternative to amphotericin B used for selective digestive decontamination, physicians asked the hospital pharmacy for the preparation of nystatin capsules $500000 \mathrm{IU}$

Methods Three methods were considered for the routine control: liquid chromatography (LC), flow injection analysis (FIA) and ultraviolet (UV) spectrophotometry. An isocratic LC method with UV detection was developed. A Hypersil BDS C18 column (150 mm $\times 4.6 \mathrm{~mm}, 5 \mu \mathrm{m}$ ) thermostated at $30^{\circ} \mathrm{C}$ was used as the stationary phase. The mobile phase was a mixture of $0.05 \mathrm{M}$ ammonium acetate buffer $\mathrm{pH} 6.0$ methanol $(35: 65, \mathrm{v} / \mathrm{v})$. Flow rate was $1.0 \mathrm{~mL} / \mathrm{min}$ and run time was $25 \mathrm{~min}$. Detection was operated at $305 \mathrm{~nm}$ and spectra were registered between 190 and $400 \mathrm{~nm}$. $10 \mu \mathrm{L}$ were injected. FIA used LC equipment in which the stationary phase was replaced by a PEEK capillary (164 cm, $0.13 \mathrm{~mm}$ internal diameter) with water flow $\left(1.0 \mathrm{~mL} / \mathrm{min} ; 25^{\circ} \mathrm{C}\right) .10 \mu \mathrm{L}$ were injected. UV spectrophotometry used a double beam spectrophotometer set at $305 \mathrm{~nm}$.

Solutions of nystatin (reference and samples) were prepared in methanol for FIA and LC $(0.36 \mathrm{mg} / \mathrm{mL})$. For UV spectrophotometry, a subsequent dilution $(1: 50, \mathrm{v} / \mathrm{v})$ with ammonium acetate buffer/methanol $(50: 50, \mathrm{v} / \mathrm{v})$ was needed.

Results The three methods were validated according to $\mathrm{ICH}$ guidelines. In the case of $\mathrm{LC}$, ruggedness of the method was tested. Three batches of hospital preparations were analysed by each method.

Conclusions For routine control, UV spectrophotometry or FIA would be the methods of choice (rapid, easy). The LC method could be used to perform stability studies.

\section{INTRODUCTION}

The concept of selective digestive decontamination (SDD) is required in different hospital services such as the haematology-oncology service. SDD is prescribed for patients admitted for marrow transplantation. The SDD protocol consists of prescription of antibiotic capsules (colistin + gentamicin) in association with an oral antifungal (amphotericin B). The care team met significant reluctance from patients to take the antifungal. This reluctance came from the unpleasant taste of amphotericin B, leading to non-compliance. Faced with this problem, the medical team asked the hospital pharmacy to prepare nystatin capsules, which can be used as an alternative to amphotericin B. ${ }^{1}$ Any hospital pharmaceutical preparation should be analysed before delivery to patients.

Nystatin is a multicomponent antibiotic, the main component being nystatin A1 (figure 1). Generally, the analytical method used for the assay of the active substance and the finished products is a microbiological method. ${ }^{2-5}$

This kind of method is time consuming and it cannot be used on a routine basis to obtain rapid control of hospital preparations. Some analytical procedures, often based on liquid chromatography (LC) mass spectrometry, have been described for the determination of nystatin in biological tissues, ${ }^{6-8}$ but they are not adapted for the control of hospital preparations.

In fact, few LC methods have been described for the control of nystatin in pharmaceutical preparations: in a mouthwash in combination with lidocaine and hydrocortisone using a gradient method ${ }^{9}$ in a commercial ointment for a stability study but with a rapid elution which does not take into account separation of the 'other compound' with relative high content $(\max 4.0 \%) ;^{10}$ in different pharmaceutical preparations. ${ }^{11}$

The aim of this work was to develop and validate three analytical methods for the routine control of nystatin capsules, offering some flexibility by taking into account the equipment available in hospital pharmacies. We simultaneously consider flow injection analysis (FIA), ultraviolet (UV) spectrophotometry and LC. FIA is used daily in our hospital pharmacy to control cytotoxic preparations and its use in pharmaceutical analysis was recently reviewed. $^{12} \mathrm{UV}$ spectrophotometry is a common alternative to LC for routine control of hospital preparations. Even if these two methods are not stability indicating, they can be useful for rapid control at batch release. LC was also considered because it is a method that indicates stability and in case of doubt or litigation it is the only mandatory method as recommended by the French National Formulary. $^{13}$

\section{MATERIALS AND METHODS \\ Reagents and samples}

Ammonium acetate, acetic acid 100\%, ammonia min 25\%, mannitol and methanol (LC grade) were purchased from VWR (F-94120 Fontenay-sous-bois). LC grade water was obtained from PURELAB ultra ELGA (F92-160 Antony) equipment. 


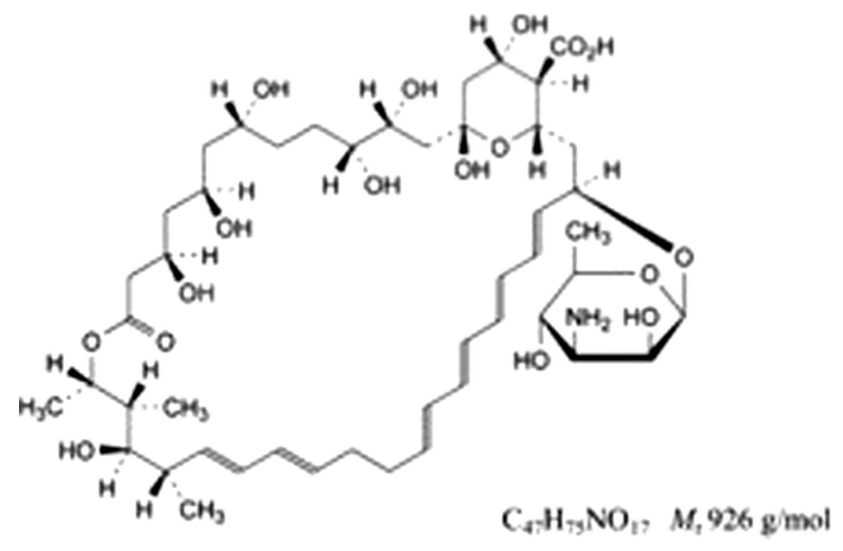

Figure 1 Formula of nystatin A1.

Nystatin was purchased from FAGRON (F-75008 Paris) and complied with the relevant European Pharmacopoeia (Ph. Eur.) monograph.

The pharmaceutical formulation was a hard capsule (size 2) containing nystatin $(82.44 \mathrm{mg}$ corresponding to $500000 \mathrm{IU}$; $72.95 \% \mathrm{~m} / \mathrm{m}$ ) and mannitol $(31.05 \mathrm{mg} ; 27.05 \% \mathrm{~m} / \mathrm{m})$ with a unitary weight of approximately $113 \mathrm{mg}$. Three batches of 200 capsules were manufactured by three different operators. They comply with the test for uniformity of dosage units determined by mass variations according to the Ph. Eur. (chapter 2.9.40).

\section{Instrumentation}

The LC equipment (Elite LaChrom VWR/Hitachi) consisted of an organiser for four solvents, a quaternary pump (L-2130), an autosampler (L-2200), a column oven (L-2300) and a diode array detector (DAD) (L-2455). The acquisition and reprocessing of data were supported by EZChrom Elite software (VWR/ Agilent).

The FIA consisted of an LC system (Ultimate 3000, Dionex F-91969 Courtaboeuf Cedex) with an organiser for six solvents (SRD-3600), a double ternary pump (DGP-3600A), a thermostated autosampler (WPS-300 TSL), a thermostated column compartment (TCC-3200) and a DAD (PDA-3000). The column was replaced by a PEEK capillary $(164 \mathrm{~cm}, 0.13 \mathrm{~mm}$ internal diameter). Data acquisition was supported by Chromeleon V.6.80 (Dionex Corporation, Sunnyvale, California, USA).

The UV equipment was a double beam UV $\mathrm{mc}^{2}$ spectrophotometer (SAFAS, F-98000 Monaco), equipped with a multi-cell rail. The data were stored and reprocessed with the associated software (SAFAS).

The $\mathrm{pH}$ measurements were performed on a $93313 \mathrm{pH}$ meter (Fischer Bioblock Scientific; F-67403 Illkirch) with a combined electrode and a temperature sensor.

\section{Experimental conditions}

Chromatographic separations were achieved on an end-capped C18 column Hypersil BDS C18, $150 \mathrm{~mm} \times 4.6 \mathrm{~mm}, 5 \mu \mathrm{m}$ (Interchim F-03100 Montluçon). The experiments were performed at $30^{\circ} \mathrm{C}$ and the samples were stored before injection on auto-sampler at $15^{\circ} \mathrm{C}$. The mobile phase was a mixture of ammonium acetate $(\mathrm{pH} 6.0 ; 0.05 \mathrm{M})$ and methanol $(35: 65, \mathrm{v} / \mathrm{v})$. The flow rate was $1.0 \mathrm{~mL} / \mathrm{min}$, the injection volume was $10 \mu \mathrm{L}$ and the run time was $25 \mathrm{~min}$. Detection was operated at $305 \mathrm{~nm}$.

FIA was performed with ultrapure water as the mobile phase at a flow rate of $1.0 \mathrm{~mL} / \mathrm{min}$. Capillary temperature and sample temperature were set at $25^{\circ} \mathrm{C}$. The injection volume was $10 \mu \mathrm{L}$. Detection was operated at $305 \mathrm{~nm}$.

For UV spectrophotometry, measurements were performed at $305 \mathrm{~nm}$ at a rate of $0.1 \mathrm{~s}$ per cell. For the three methods, the spectra were stored from 190 to $400 \mathrm{~nm}$.

\section{Buffer solutions}

Ammonium acetate buffer $(0.05 \mathrm{M}) \mathrm{pH}=6.0$ (LC mobile phase)

Dissolve $3.85 \mathrm{~g}$ of ammonium acetate in $900 \mathrm{~mL}$ of water, adjust the $\mathrm{pH}$ if necessary with ammonia or acetic acid, and dilute to $1000.0 \mathrm{~mL}$ with water. Filter with filter $0.22 \mu \mathrm{m}$.

Ammonium acetate buffer $\mathrm{pH}=6.0$ (for UV spectrophotometry) Dissolve $200 \mathrm{~g}$ of ammonium acetate in $600 \mathrm{~mL}$ of water and add $8.2 \mathrm{~mL}$ of glacial acetic acid, adjust the $\mathrm{pH}$ if necessary with ammonia or acetic acid, and dilute to $1000.0 \mathrm{~mL}$ with water.

\section{Sample preparation}

\section{Reference solution for assay}

Nystatin $(36.0 \mathrm{mg}$ ) was introduced in a $100.0 \mathrm{~mL}$ volumetric flask with approximately $50 \mathrm{~mL}$ of methanol and dissolved in an ultrasonic bath. After cooling, the solution was made up to $100.0 \mathrm{~mL}$ with the same solvent (FIA and LC).

For analysis by UV spectrophotometry, $2.0 \mathrm{~mL}$ of the previous solution were diluted to $100.0 \mathrm{~mL}$ with the solvent mixture.

\section{Test solution for assay}

An amount of $50.0 \mathrm{mg}$ of homogenised powder corresponding to $36.5 \mathrm{mg}$ of nystatin were introduced in a $100.0 \mathrm{~mL}$ volumetric flask with $50 \mathrm{~mL}$ of methanol and dissolved in an ultrasonic bath. After cooling, the volume was made up to $100.0 \mathrm{~mL}$ with the same solvent before analysis by FIA or LC.

For analysis by UV spectrophotometry, the test solution was prepared as previously described.

\section{RESULTS AND DISCUSSION}

\section{Development of the LC method}

Nystatin is a highly unsaturated antifungal antibiotic produced by Streptomyces noursei. The principal component is nystatin A1, the amount of which (minimum $85.0 \%$ ) is determined in the Ph. Eur. monograph using a test called 'composition' and gradient LC reversed phase chromatography. The content in active substance is determined by a microbiological assay. So, the objective was to develop a rapid isocratic method to determine the content of nystatin A1 in the finished product. Taking as a starting point the compendial chromatographic method, we switch to isocratic conditions by keeping the same volatile buffer and replacing acetonitrile with methanol for cost reasons and by decreasing the run time from $55 \mathrm{~min}$ to $20-30 \mathrm{~min}$, keeping some selectivity regarding the related components and compliance to the same system suitability criteria. A mixture of ammonium acetate $(\mathrm{pH} 6.0 ; 0.05 \mathrm{M})$ and methanol $(35: 65, \mathrm{v} / \mathrm{v})$ as the mobile phase was found to give a retention time of about 8 min for nystatin A1, the system suitability criteria being easily met (resolution 5.8 for a specification of 3.5) and the signal/ noise ratio for the disregard limit $(0.1 \% \mathrm{~m} / \mathrm{m})$ having a value of 26. As the detection was performed with a DAD, use of spectral data was possible. Nystatin exhibits a characteristic UV spectrum with three intense and sharp bands in the region between 280 and $340 \mathrm{~nm}$, an additional band at $231 \mathrm{~nm}$, and also a minor inflection at $280 \mathrm{~nm}^{14}$ This very characteristic spectrum was used to identify the peaks obtained in LC. 


\section{Characterisation of the peak of nystatin A1}

In the isocratic system, nystatin A1 is eluted in about $8 \mathrm{~min}$ instead of about $16 \mathrm{~min}$ in the Ph. Eur. method (figure 2).

The peak of nystatin A1 has the following chromatographic parameters: asymmetry (0.95), number of theoretical plates (2940) and capacity factor $\left(k^{\prime}=4.2\right)$. It was also important to check the purity of the peak using the information given by EZChrom Elite software. To achieve this, the UV spectra of the nystatin peak (190-400 nm) obtained by the developed method were compared with those obtained for nystatin using the 'reference' method of the composition test from the Ph. Eur. This comparison was expressed as a similarity factor. A value higher than 0.980 was taken as a threshold value. The value at the peak apex was 0.9981 . As the elution was faster in the isocratic system, it was important to check if some minor peaks were co-eluted with the peak of nystatin A1. So, the similarity factors were calculated at $5 \%$ of peak height 'up slope' $(0.9981)$ and 'down slope' (0.9996). These values were identical to those found for the peak of nystatin A1 using the Ph. Eur. method (0.9989 and 0.9987 respectively).

\section{Related substances peaks}

The chromatographic profiles obtained by the two methods were compared taken into account the threshold value of 0.980 for the similarity factor. The number of peaks before the nystatin A1 peak (relative retention $(\mathrm{RR})<1.00$ ) and after the nystatin A1 peak $(R R>1.00)$ were the same, two and four respectively (table 1 ).

The characteristics of the nystatin A1 peak and the number of secondary peaks were the same for the isocratic-developed method and the gradient method from the Ph. Eur. monograph.

\section{Content in nystatin A1}

The content in nystatin A1 was determined by normalisation because currently there is no nystatin A1 reference substance available. Using the Ph. Eur. method, the mean nystatin A1 content was 94.0\% $(n=6, C V=0.32 \%)$ and for the in-house method, the mean content was $95.6 \%(n=6, C V=0.15 \%)$. The content obtained by the two methods complies with the Ph. Eur. specification (minimum 85.0\%) and no statistically difference was observed (Student's test, $\mathrm{p}<0.05$ ). In comparison to the method developed by Pendela et al, ${ }^{9}$ this method uses isocratic elution. Moreover, it keeps selectivity for structurally related compounds of nystatin.

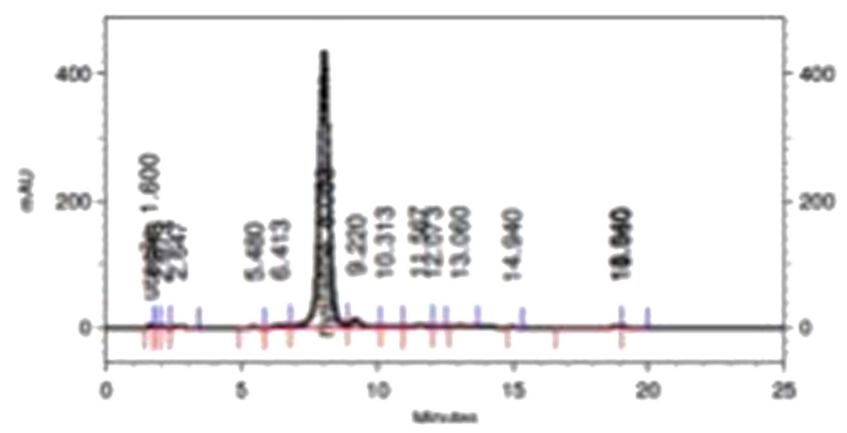

Figure 2 Typical chromatogram obtained with the in-house method. End-capped C18 column Hypersil BDS C18, $150 \mathrm{~mm} \times 4.6 \mathrm{~mm}, 5 \mu \mathrm{m}$, ammonium acetate ( $\mathrm{pH} 6.0 ; 0.05 \mathrm{M})$, methanol $(35: 65, \mathrm{v} / \mathrm{v})$.
Table 1 Interpretation of chromatograms obtained by in-house and European Pharmacopoeia methods: similarity factors, relative retention (RR), mean area (\%)

\begin{tabular}{|c|c|c|c|}
\hline & Similarity factor* & RRt & Mean areat \\
\hline \multicolumn{4}{|c|}{ In-house method } \\
\hline Peak 1 & 0.796 & 0.17 & 0.20 \\
\hline Peak 2 & 0.998 & 0.59 & 0.26 \\
\hline Peak 3 & 0.998 & 0.74 & 0.86 \\
\hline Nystatin & & 1.00 & 95.5 \\
\hline Peak 4 & 0.999 & 1.14 & 0.28 \\
\hline Peak 5 & 0.993 & 1.36 & 0.27 \\
\hline Peak 6 & 0.999 & 1.60 & 0.90 \\
\hline Peak 7 & 0.997 & 1.73 & 0.42 \\
\hline Peak 8 & 0.928 & 2.04 & 0.40 \\
\hline Peak 9 & 0.884 & 2.61 & 0.86 \\
\hline \multicolumn{4}{|c|}{ European pharmacopoeia method } \\
\hline Peak 1 & 0.994 & 0.50 & 0.59 \\
\hline Peak 2 & 0.999 & 0.83 & 0.92 \\
\hline Nystatin & & 1.00 & 94.2 \\
\hline Peak 3 & 0.999 & 1.13 & 0.32 \\
\hline Peak 4 & 0.999 & 1.31 & 1.43 \\
\hline Peak 5 & 0.993 & 1.58 & 0.34 \\
\hline Peak 6 & 0.915 & 1.67 & 0.46 \\
\hline Peak 7 & 0.994 & 1.80 & 0.76 \\
\hline Peak 8 & 0.815 & 1.96 & 0.97 \\
\hline Peak 9 & 0.485 & 2.00 & 0.62 \\
\hline
\end{tabular}

\section{FIA method}

The FIA method was validated since the equipment was available at the hospital pharmacy and was used daily for control of cytotoxic preparations. The method is rapid, easy to handle, and suitable for routine control at batch release.

The only factor needing optimisation is the injection volume to obtain an absorbance of around $145 \mathrm{mUA} ; 10 \mu \mathrm{L}$ of reference and test solutions were injected and detection was operated at $305 \mathrm{~nm}$.

\section{UV-spectrophotometry method}

UV spectrophotometry was chosen because it is usually described in the French National Formulary as an alternative method for control of pharmaceutical preparations.

Previous reference and test solutions were diluted to obtain an absorbance of around 0.5 . A dilution of $1 / 50 \mathrm{v} / \mathrm{v}$ is suitable (nystatin $7.2 \mu \mathrm{g} / \mathrm{mL}$ ).

\section{Validation}

Method validation was carried out according to ICH guideline Q2(R1), ${ }^{15}$ and statistics tests were realised by Statgraphics. ${ }^{16}$ The results are shown in table 2 .

\section{Specificity}

Mannitol is the only excipient present in the composition of nystatin capsules. The specificity was tested by injection of a solution of mannitol corresponding to the final concentration in the sample $(0.14 \mathrm{mg} / \mathrm{mL})$. It was confirmed that mannitol does not have any absorption at $305 \mathrm{~nm}$. 
Table 2 Figures of merit for LC, FIA and UV spectrophotometry

\begin{tabular}{|c|c|c|c|}
\hline Figures of merit & LC & FIA & $\begin{array}{l}\text { UV } \\
\text { spectrophotometry }\end{array}$ \\
\hline $\begin{array}{l}\text { Specificity } \\
\text { (mannitol) }\end{array}$ & No interference & No interference & No interference \\
\hline $\begin{array}{l}\text { Linearity } \\
(50.0-150.0 \%)\end{array}$ & $r^{2}=0.9975$ & $r^{2}=0.9991$ & $r^{2}=0.9968$ \\
\hline Accuracy $(n=15)$ & $\begin{array}{l}\mu=99.6 \% \\
95 \% \mathrm{Cl}(98.0 \\
\text { to } 101.2)\end{array}$ & $\begin{array}{l}\mu=100.4 \% \\
95 \% \mathrm{Cl}(98.9 \\
\text { to } 101.9)\end{array}$ & $\begin{array}{l}\mu=100.5 \% \\
95 \% \mathrm{Cl}(98.4 \text { to } \\
102.6)\end{array}$ \\
\hline $\begin{array}{l}\text { Repeatability } \\
(n=6,3 \text { days) }\end{array}$ & $\begin{array}{l}\mathrm{CV}_{1}=0.83 \% \\
\mathrm{CV}_{2}=0.88 \% \\
\mathrm{CV}_{3}=0.83 \%\end{array}$ & $\begin{array}{l}\mathrm{CV}_{1}=1.3 \% \\
\mathrm{CV}_{2}=1.1 \% \\
\mathrm{CV}_{3}=1.2 \%\end{array}$ & $\begin{array}{l}\mathrm{CV}_{1}=1.1 \% \\
\mathrm{CV}_{2}=1.4 \% \\
\mathrm{CV}_{3}=1.8 \%\end{array}$ \\
\hline $\begin{array}{l}\text { Intermediate } \\
\text { precision }(n=18)\end{array}$ & $\mathrm{CV}=0.82 \%$ & $C V=2.0 \%$ & $C V=2.0 \%$ \\
\hline
\end{tabular}

FIA, flow injection analysis; LC, liquid chromatography; UV, ultraviolet.

\section{Linearity and range}

Five different concentrations in a range from $50.0 \%$ to $150.0 \%$ of the theoretical concentration $(0.36 \mathrm{mg} / \mathrm{mL})$ were analysed in triplicate. For each method, linearity was obtained $\left(\mathrm{r}^{2}>0.99\right)$ (table 2).

\section{Accuracy}

The accuracy was achieved from the analysis of synthetic mixtures obtained by spiking mannitol with known amounts of nystatin in a concentration range from $50.0 \%$ to $150.0 \%$. Each solution was analysed three times. The three methods can be considered accurate since 100\% is included in the confidence interval (table 2).

\section{Repeatability and intermediate precision}

Repeatability was obtained from six repetitions of the analysis of nystatin capsules. Intermediate precision was obtained by repeating the determination of nystatin A1 content on three different days. The repeatability of each method was demonstrated and the coefficients of variation of the intermediate precision were considered satisfactory $(\leq 2.0 \%)$, especially considering the specification for the content of nystatin in the finished product (90.0-110.0\%) (table 2).

\section{Robustness}

The robustness of a method is its capacity to give expected results even when varying characteristic factors in a narrow range around the validated values. As LC was the most evolved of the three methods, its robustness was studied taking into account the specific chapter described in the $\mathrm{Ph}$. Eur. for the authorised adjustments of the factors relative to an isocratic LC method. ${ }^{17}$ The influence of the following factors was tested: composition of the mobile phase (percentage of organic phase, $\mathrm{pH}$ and buffer concentration), flow rate and column temperature at the maximal extent allowed. For each experimental condition, the values for the system suitability and the retention time for nystatin A1 have been reported in table 3 .

Regarding the influence of $\mathrm{pH}$ and molarity buffer, flow rate and temperature, the method was robust since the specification for resolution in the system suitability test was met in all cases.

As expected, the composition of the mobile phase was the critical parameter. The resolution decreased with increasing elution strength of the mobile phase and the initial composition of the mobile phase, $0.05 \mathrm{M}$ ammonium acetate buffer $\mathrm{pH} 6.0$ and methanol $(35: 65, \mathrm{v} / \mathrm{v})$, should be strictly observed.

\section{ANALYSIS OF BATCHES}

Three different operators manufactured three batches of nystatin capsules on different days. The variation between capsules was taken into account by compliance with the test of 'Uniformity of dosage units' (Ph. Eur. Chapter 2.9.40). Assay of nystatin was performed using an isocratic LC method, UV spectrophotometry and FIA (table 4). The results comply with the specification of $90.0-110.0 \%$.

\section{CONCLUSION}

The development of analytical methods in place of the timeconsuming and non-specific microbiological assay to perform routine control of nystatin capsules was useful.

Three methods-FIA, UV spectrophotometry and isocratic LC-were developed and validated according to ICH Q2(R1). ${ }^{15}$

Table 3 Parameters adjustments, tested values and results obtained for robustness

\begin{tabular}{|c|c|c|c|c|}
\hline Parameters (Rs>3.5) & Authorised adjustments & Tested values & System suitability $(\mathrm{R}>3.5)$ & $\begin{array}{l}\text { Nystatin } \mathrm{A} 1 \\
\text { retention time (min) }\end{array}$ \\
\hline $\begin{array}{l}\text { Ammonium acetate buffer } 0.05 \mathrm{M} \\
\mathrm{pH}=6.0 \text {, methanol } 35 / 65(\mathrm{v} / \mathrm{v})\end{array}$ & $\begin{array}{l}\text { Proportion of ammonium } \\
\text { acetate buffer: } \pm 30 \% \text { relative }\end{array}$ & $\begin{array}{l}25: 75(\mathrm{v} / \mathrm{v}) \\
30: 70(\mathrm{v} / \mathrm{v}) \\
35: 65(\mathrm{v} / \mathrm{v}) \\
40: 60(\mathrm{v} / \mathrm{v}) \\
45: 55(\mathrm{v} / \mathrm{v})\end{array}$ & $\begin{array}{l}1.8 \\
1.9 \\
5.4 \\
7.3 \\
8.3\end{array}$ & $\begin{array}{l}\text { No separation } \\
\text { Incomplete separation } \\
8.1 \\
15.7 \\
37.5\end{array}$ \\
\hline pH buffer: 6.0 & \pm 0.2 & $\begin{array}{l}5.8 \\
6.0 \\
6.2\end{array}$ & $\begin{array}{l}6.3 \\
5.4 \\
5.9\end{array}$ & $\begin{array}{l}8.0 \\
8.1 \\
8.1\end{array}$ \\
\hline Buffer molarity: $0.05 \mathrm{M}$ & $\pm 10 \%$ & $\begin{array}{l}0.045 \mathrm{M} \\
0.05 \mathrm{M} \\
0.055 \mathrm{M}\end{array}$ & $\begin{array}{l}5.8 \\
5.4 \\
6.2\end{array}$ & $\begin{array}{l}8.1 \\
8.1 \\
8.1\end{array}$ \\
\hline Flow rate: $1.0 \mathrm{~mL} / \mathrm{min}$ & $\pm 50 \%$ & $\begin{array}{l}0.5 \mathrm{~mL} \\
1.0 \mathrm{~mL} \\
1.5 \mathrm{~mL}\end{array}$ & $\begin{array}{l}7.4 \\
5.4 \\
4.9\end{array}$ & $\begin{array}{l}16.9 \\
8.1 \\
5.5\end{array}$ \\
\hline Column temperature: $30^{\circ} \mathrm{C}$ & $\pm 10^{\circ} \mathrm{C}$ & $\begin{array}{l}20^{\circ} \mathrm{C} \\
30^{\circ} \mathrm{C} \\
40^{\circ} \mathrm{C}\end{array}$ & $\begin{array}{l}6.4 \\
5.4 \\
6.0\end{array}$ & $\begin{array}{l}10.2 \\
8.1 \\
6.8\end{array}$ \\
\hline
\end{tabular}


Table 4 Analysis of three batches of nystatin capsules $(n=6)$

\begin{tabular}{llll}
\hline & Batch 1 & Batch 2 & Batch 3 \\
\hline LC & $99.0 \%$ & $99.1 \%$ & $97.9 \%$ \\
FIA & $\mathrm{CV}=0.85 \%$ & $\mathrm{CV}=0.78 \%$ & $\mathrm{CV}=0.18 \%$ \\
\multirow{3}{*}{ UV spectrophotometry } & $97.1 \%$ & $100.0 \%$ & $99.5 \%$ \\
& $\mathrm{CV}=0.69 \%$ & $\mathrm{CV}=0.30 \%$ & $\mathrm{CV}=0.95 \%$ \\
& $95.7 \%$ & $95.8 \%$ & $96.6 \%$ \\
& $\mathrm{CV}=1.06 \%$ & $\mathrm{CV}=1.15 \%$ & $\mathrm{CV}=1.73 \%$ \\
\hline
\end{tabular}

FIA, flow injection analysis; LC, liquid chromatography; UV, ultraviolet.

UV spectrophotometry or FIA will be the method of choice at batch release since they are rapid and easy to handle. LC is useful as a reference method and could be used to perform stability studies and in case of litigation.

\section{Key messages}

What is already known on this subject

- Few liquid chromatography (LC) methods have been described for control of nystatin in pharmaceutical preparations: in a mouthwash in a mixture with lidocaine and hydrocortisone using a gradient method; in a commercial ointment product for a stability study but with a rapid elution which does not take into account separation of the 'other compound' with relatively high content (max 4.0\%); and in different pharmaceutical preparations.

- There is no assay for the routine control of nystatin capsules suitable for hospital pharmacies.

\section{What this study adds}

- Control of nystatin capsules was performed by three analytical methods: LC diode array detector (DAD), flow injection analysis (FIA) and ultraviolet (UV) spectrophotometry, offering some flexibility by taking into account the equipment available in hospital pharmacies.

- The isocratic LC DAD method was developed and validated.
Acknowledgements The authors would like to thank N Sobalak from the hospital pharmacy for her technical help during chromatographic and data processing.

Competing interests None.

Patient consent Obtained.

Provenance and peer review Not commissioned; externally peer reviewed.

\section{REFERENCES}

1 AFSSAPS. Utilisation de préparations hospitalières dans la décontamination digestive sélective. November 2007. http://nosobase.chulyon;fr/recommandations/afssaps/ 2011_DDS_AFSSAPS.pdf

2 USP 37 NF 32. The United States Pharmacopoeia. Rockville, MD, USA. http://www. usp.org

3 Japanese Pharmacopoeia, 15th edition. http://www.pmda.go.jp/english/pharmacopeia

4 European Pharmacopoeia, Nystatin 01/2008:05/7, DEQM. Council of Europe, Strasbourg.

5 British Pharmacopoeia. 2014. London: The Stationery Office.

6 Bruheim P, Borgos SEF, Tsan P, et al. Chemical diversity of polyene macrolides produced by Streptomyces noursei ATCC 11455 and recombinant strain ERD44 with genetically altered polyketide synthase NysC. Antimicrob Agents Chemother 2004;48:4120-9.

7 Scheuch F, Gießmann T, Siegmund W. Quantitative determination of nystatin in human plasma using LC-MS after inhalative administration in healthy subjects. J Chromatogr B 2006;844:84-8.

8 Llabot JM, Allemandi DA, Manzo RH, et al. HPLC method for the determination of nystatin in saliva for application in clinical studies. J Pharm Biomed Anal 2007:45:526-30

9 Pendela M, Kahsay G, Baekelandt I, et al. Simultaneous determination of lidocaine hydrochloride, hydrocortisone and nystatin in a pharmaceutical preparation by RP-LC. J Pharm Biomed Anal 2011;56:641-4.

10 Cione APP, Liberale MJ, Da Silva PM. Development and validation of an HPLC method for stability evaluation of nystatin. Braz J Pharm Sci 2010;4:305-10.

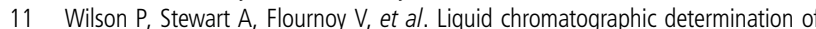
nystatin in pharmaceutical preparations. J AOAC Int 2001;84:1050-6.

12 Tzanavaras PD, Themelis DG. Review of recent applications of flow injection spectrophotometry to pharmaceutical analysis. Anal Chim Acta 2007;588:1-9.

13 Formulaire National, ANSM. http://ansm.sante.fr/mediatheque/publications/ pharmacopee-francaise-formulaire-national

14 Michel GW. Nystatin. Anal Profile Drug Substances 1977;6:241-421.

$15 \mathrm{ICH}$ Q2(R1). Validation of analytical procedures: text and methodology. http://www. ich.org

16 Caporal-Gautier J, Nivet JM, Algranti P, et al. Guide de validation analytique. Rapport d'une commission SFSTP. I: Méthodologie. STP Pharma Prat 1992;2:205-26.

17 European Pharmacopoeia, Chapter 2.2.46: Chromatographic separation techniques. DEQM, Council of Europe, Strasbourg. 